\title{
Research on the Effectiveness of Mathematics Teaching Based On Network Questionnaire: A Teacher Perspective
}

\author{
$\mathrm{Na}$ Cheng \\ School of Science, Xihua University, 610031Chengdu, Sichuan, China \\ miniqiangying@163.com
}

\begin{abstract}
At present, lack of teaching effectiveness has become a serious problem in college, especially in the public mathematics courses. This paper attempts to study the effectiveness of mathematics classroom teaching through the network survey, as the Internet becomes popular media, Internet survey will become a mainstream form of investigation. The results show that teachers are more inclined to lecture style and question type teaching in mathematics course, while students prefer to explore cooperative learning mode. At the same time, 28\% students never participate in course interaction, and $22 \%$ students only participate in course interaction which he thinks important. So that, how to mobilize the enthusiasm of the students is the main factor to improve the efficiency of classroom teaching. Generally speaking, effective teaching is comprehensive, dynamic and comprehensive, it should not only let the students get the basic knowledge, but also teach them the corresponding learning methods.
\end{abstract}

Keywords: Network Questionnaire, Mathematics Teaching, Classroom Efficiency, Autonomous Learning

\section{Introduction}

University classroom is the main place for college students to cultivate talents, but at present the phenomenon of the lack of effectiveness of classroom teaching, especially in the classroom teaching of Public Mathematics courses. With the enlargement of the scale of colleges and universities and the increasing complexity of the students, the phenomenon of the quality of the teaching quality of the University's public mathematics course is an indisputable fact [1]. Classroom teaching efficiency is not high, the lack of creativity, the student classroom learning quality is low is the current university public mathematics classroom teaching in the existence of serious drawbacks. Classroom teaching is the main way of cultivating talents in University, a careful look at the problems existing in the classroom teaching, and effectively improve the effectiveness of classroom teaching in universities is one of the urgent tasks of current reform of higher education. This paper attempts to study the effectiveness of mathematics classroom teaching through the network survey, network survey method is with the development of network technology and the rise of a new social survey method,. Surfing the Internet has become a part of people's work, study and life. As a kind of new way to adapt to the change of the information media, the network survey has been made and has a considerable degree of application [2]. We call this online survey network survey. In Europe and the United States and other developed countries in the Internet, the market and public opinion on the network has been quite common, thousands of sites, hundreds of thousands of English web containing the survey section. Abroad has developed software for online survey, and began to explore the use of Internet to implement the general statistical survey. Domestic network survey has also started, such as CNNIC and other agencies have held a number of surveys on the development of the Internet in china. In spite of the current network survey has become a new force, but with the Internet as a 
popular information dissemination media, network survey will become a mainstream form of investigation. Effective classroom teaching is that teachers to follow the objective law of the teaching activity on the basis, in the specific category of teaching, with as little input to obtain good teaching effect, in order to achieve the expected teaching goal to meet the educational value of social and personal needs.

On the effectiveness of mathematics classroom teaching, from different angles have different understanding. From a mathematical point of view, mathematics classroom teaching is effective or not, is a question about the value of mathematics education. The value of mathematics education refers to the value of mathematics education on the human development [3-4]. As the main body of education of teachers and students in teaching plays a major role, teachers in the teaching process plays a leading role, determines the density and difficulty of teaching content, teaching process is controlled, affects the student's main body status; students in teaching activities occupy the main body status, education to the first point of departure and the ultimate embodiment. With respect to the effective teaching, there are some differences in the effectiveness of classroom teaching: firstly, teaching goal, the ultimate goal of effective teaching focuses on teaching, lifelong development focuses on the people, and the effectiveness of classroom teaching is focused on teaching goals, namely, to reach the target in a certain stage of teaching in the second degree; the evaluation results, from the teaching point of view, the validity of teaching focuses on teaching evaluation results, but these are almost always in scores as evaluation criteria, the validity and the effectiveness of classroom teaching is focused on teaching process, learning cultivate students' learning ability, to stimulate interest in learning; thirdly, from the teaching results look, the effective teaching focuses on the satisfaction degree of the social and individual education, and the effectiveness of classroom teaching focuses on teaching efficiency. The effectiveness of classroom teaching is difficult to make accurate evaluation in a short time, it is difficult to accurately measure in some way, and it involves more complex factors.

\section{Literature Review}

\subsection{College Teaching Effectiveness}

In the $1980 \mathrm{~s}$, countries all over the world for the effective teaching were a lot of research, and published many relevant monographs, these research mainly the influence of teacher characteristics and teaching behavior of students, teachers from the perspective of research on teachers influence on effective teaching. The relationship between the later researches on this aspect will shift the focus of research on classroom teaching and students' academic achievement and self-development [5]. The book mainly through the description of the specific behavior of the course, reflect the teaching process how to let the students in a positive learning state, how to improve the efficiency of classroom teaching. Since the 20th century, many psychologists to student's learning psychology were study, learn a lot about psychological concepts, rules and process was found and the. Learning conditions, the work of this study psychology and Constructivist Psychology through the application of information processing psychology, formed a theoretical system to explain the vast majority of classroom learning. Students learning content is not given to teachers, but to think like a mathematician to think about mathematics, to find mathematics, the knowledge into their own cognitive structure. Bruner pointed out that in the process of teaching, teachers should try to arouse the students' interest in mathematics, to promote students' thinking found, in discovering knowledge, experience knowledge recreation, so as to let the students have a sense of achievement of learning, to get the joy of learning, to increase interest in learning mathematics. According to different ways, learning is divided into mechanical learning and meaningful learning, discovery learning and learning. 
Effective teaching strategies include the strategies of teachers' teaching and students' learning strategies. With so many books from the perspective of students focuses on learning strategies, such as meta cognitive strategy and solve strategy, scientific use of time strategy; and other works is from the point of view of a teacher of research on Teachers' teaching strategies, such as classroom observation, classroom questioning strategy. Of course, there is a certain relationship between the effectiveness of teaching and teaching environment. That is to say, in the process of teaching, the creation of consciousness is conducive to the teaching environment for students to learn. In fact, foreign studies for effective teaching research experience from the teacher to the students, by the students to the teaching environment, by the effectiveness of teaching to classroom teaching effectiveness of the development process [6]. In twenty-first century, countries around the world are concerned about how to improve the efficiency of teaching to promote the development of students' life. In our country, the research on effective teaching includes what are effective teaching, effective teaching, effective teaching behavior, effective teaching strategy, and effective teaching evaluation standard. Effective teaching is different from ineffective teaching, inefficient teaching, and general teaching of high efficiency teaching methods. The relevant research results show effective teaching should adopt different methods according to different types of teaching content. For example, the theoretical course to take the problem of analysis and thematic approach, methods and skills courses should be taken to video analysis and real observation method. Some scholars through the related research that the effective teaching characteristics: teachers on the teaching work of a serious and responsible, have their own characteristics and style of teaching, teaching emphasis and difficulty in prominent, clear expression, be good at arousing students' learning initiative and enthusiasm to effectively improve the learning ability of students. On the basis of previous studies, scholar generalizes the features of effective teaching: correct teaching objective, fully before class preparation, classroom management in a scientific way, clear expression, the enthusiasm of the classroom teaching, harmonious relationship between teachers and students, classroom time efficiently use and inspire students.

\subsection{Classroom Teaching of Mathematics}

From a professional point of view, the effectiveness of classroom teaching by means of classroom teaching to enable students to obtain development. Generally speaking, the effectiveness of classroom teaching by means of classroom teaching activities, students' academic gains, have improved, there is progress. Specific performance in: Students' cognitive, do not know how to understand, much less known to know, never to attend; in emotion, never love to love, never love to love, never interested in interest. The characteristics of the effectiveness of classroom teaching) can cite a lot but the most essential point is to see whether the students are willing to learn, take the initiative to learn and how to learn. In mathematics classroom every day, we can see clearly the reasons affecting the effectiveness of teaching, first in class learning opportunity disparity, part of students' practical and less time [7]. The density of classroom teaching is the rational use of teaching activities in the class time and the proportion of total time. In order to improve the efficiency of classroom teaching, should try to improve the general teaching density, but also the appropriate master special density. However, the survey found that in mathematics classroom, generally due to the presence of teachers to spend time with students in violation of discipline, teacher class digression or terms, teachers and students to appear a lot of unnecessary movement phenomenon. Some one-sided emphasis on the increased density of special teaching, neglecting mathematics understanding in classroom, consolidate and the old and the new knowledge of mathematics comprehensive through teaching, so that students for mathematical knowledge is not solid to affect subsequent learning, resulting in a decline in the efficiency of teaching. At the same time, not only the quantity of teaching density, more 
quality. The same time can be used for teaching, memory and understanding, also can be used for analysis, comprehensive and creative learning activities. In the teaching for too much lower learning tasks in time for the cultivation of high-level innovative thinking time is reduced, the density of large quantity and poor quality of teaching.

Again, the teaching level of teachers is low, students' knowledge transfer ability is also reflected a lack of effectiveness of the cause. The modern theory of teaching according to the teaching level of classroom teaching is divided into memory, level of understanding and thinking level of level three types [8]. Memory of classroom teaching the basic characteristics of teacher individually speaking, students' passive listening, from the logical relationship between teaching and learning, often is "no learning to teach, the lack of knowledge transfer. Understanding teaching emphasizes system to understand and remember the teaching contents, but the students understand the teachers' understanding is passive. It is often the attitude and ability of the students to learn how to teach and how to learn. Thinking level of classroom teaching require students not only the memory necessary to understand, and more emphasis on under the guidance of teachers students devoted to actively participate in the whole teaching process of thinking, students are always not as full state. Most of the current classroom teaching is in the memory and understanding of the teaching level, to achieve the development of the level of minimal. Thinking of students in mathematics classroom teaching activities in widespread dependence, single, disordered, easy to understand and slow characteristics. Effectiveness, subject, from the point of view of mathematics classroom teaching in the new curriculum objectives and requirements, the main factors that affect the effectiveness of mathematics classroom teaching has five, namely education goal reached in the effectiveness and the establishment of knowledge effectiveness, teacher-student interaction in the effectiveness and the development of students.

\section{Research Design}

\subsection{Theoretical Foundations of Research}

Classroom teaching is the main position of the implementation of education, but also an important channel for the implementation of quality education. However, the current situation of education is: teaching takes a long time, students learning pressure; the efficiency of classroom teaching is low. In view of the high degree of mathematical abstraction and strict logic and so on, we need to change the traditional teaching idea, improve the efficiency of classroom teaching, improve the efficiency of learning, and reduce the pressure of student learning. Through the questionnaire survey to understand the problems existing in the mathematics classroom teaching, further understanding of the effectiveness of classroom teaching effect and in the light of these problems, put forward corresponding solutions.

At present, our country about the effectiveness of mathematics classroom teaching evaluation criteria mainly concentrated on the following points: grasp the teaching content in this section and the teaching content of position; pay attention to the individual differences between students; concise language teaching; the effective use of existing teaching resources; the flexible use of teaching plan; inspire students actively involved in classroom activities; classroom teaching can arouse students' creative; culture students' mathematical thinking ability. However these standards just in a few aspects from the perspective of teachers and students to describe the effectiveness of mathematics classroom teaching have not the classroom teaching and the external environment and personal development needs, the classroom teaching is a complicated system, and this kind of evaluation criteria is not easy to practice. In the new curriculum standard, it is pointed out that learning knowledge should promote the improvement of students' knowledge level and the development of body and mind. Teacher's "teaching" and learning of the students are the relations 
of mutual promotion and mutual support. The starting point of classroom teaching is the teaching goal, the scientific, reasonable and effective teaching goal plays an important role in classroom teaching activities, and whether the teaching goal is reasonable directly affects the effectiveness of teaching activities. In the new era background, basic knowledge is not only limited to the concept, nature, formula and theorem of mathematics teaching materials, but the study of mathematics thinking method is the tacit knowledge that students must learn. Only when the teaching goal includes ideas of mathematics study method, mathematical thinking and mathematical ability, then it will make the mathematics education keeps up with the pace of times.

\subsection{Research Method}

1) Literature research method: through the investigation of the effectiveness and the effectiveness of classroom teaching of the concerned teaching at home and abroad, and a large number of relevant literature research, some important conclusions about the effectiveness of mathematics classroom teaching.

2) Observation interview method: several times listen to different math teacher's class, and a detailed record and a serious summary. Analysis of teachers' teaching behavior, teaching strategies and students' participation in teaching activities. After several times, and teachers and students to understand the effectiveness of classroom teaching effectiveness factors, and come to a number of strategies to help the effectiveness of mathematics classroom teaching.

3) Questionnaire survey: the author use questionnaire survey of students and mathematics teachers about mathematics classroom teaching effectiveness influence factors investigation, and has carried on the detailed analysis of the summary, provide the basis for the proposed strategy to improve the effectiveness of mathematics classroom teaching.

4) Case study method: Based on this research, according to two specific mathematics classroom teaching case and analysis factors that affect the effectiveness of the classroom teaching, and give the specific improve tactics, in order to make further analysis and application of the study content.

\subsection{Factors Affecting the Effectiveness of Teaching}

The breakthrough point of quality education is to cultivate students' learning ability. Now the education reform and promoting quality education and the essence of quality education is cultivating students' learning ability and lifelong development is the social demand of modern talents, but main battlefield of talent cultivation is the classroom. In the final analysis, is to improve the efficiency of classroom teaching. Effective classroom teaching is a kind of low efficiency or invalid, and it is a new request to the modern teacher.

1) Preparation before class: in addition to the preparation of teaching materials, the students, the teaching environment is also essential to prepare lessons. First of all, teachers are prepared for the teaching content, but by teaching content is not see again and again, the lesson plan write textbooks, and to the in-depth study of the foundation of the material in this section to further grasp the teaching contents in the chapters and even the entire teaching status, a measure of its teaching value. Secondly, teachers should grasp the rich teaching resources, in the process of teaching, appropriate increase the relevant extra-curricular knowledge, to improve students' learning interest. Again, the student is the subject of education, is the main body of teaching, classroom teaching must combined with the characteristics of the student's age, psychological characteristics, learning ability, thinking ability, to improve the effectiveness of classroom teaching, so students are preparing the 
necessary link. In addition, teaching environment of teaching effect has important influence. Therefore, the teachers should according to the characteristics of the teaching content and students, make full use of existing teaching equipment to create is conducive to improve the teaching efficiency of teaching atmosphere.

2) The interaction between teachers and students: effective teacher-student interaction is the main factor to improve the students' mathematics learning ability, and the question is often a common dialogue between teachers and students. But most of the time for questions, teachers or cannot grasp the overall, or difficulty is too large, are either too simple, either cannot withhold student heart, or just pay attention to the questions and lighter than a feedback, which reduced the student to study mathematics the interest. In the course of classroom teaching, lack of teachers respect the students and care, usually attention performance excellent, enthusiastic students, to the neglect of the overall student learning mood, and could not fully understand the student's learning situation. This requires teachers to learning process and learning outcomes for students' understanding and evaluation, in order to improve the students' learning motivation, improve the efficiency of classroom teaching.

3) Class participation: Students' mathematics learning activities should not be confined to concepts, conclusions and skills, memory, imitation and accept, independent thinking, independent exploration, hands-on practice, cooperation and exchange, reading self-study etc. are an important way of learning mathematics. Students are the masters of the classroom, should participate in classroom activities, but it requires a "dominant" classroom teachers to provide a platform for them. Teachers can from the following several aspects for the students actively participate in classroom teaching activities to create conditions: shorten teaching time, leaving the students to think about the time and space; in students "zone of proximal development" should let them try to analyze and solve their own; in the process of classroom teaching can appropriate to add some extracurricular knowledge, such as those related to the history of mathematics knowledge, which helped to improve the students' learning mathematics interest, also contributed to mathematical culture transfer; classroom questioning should guide having a value, not to question the questions and ask questions later to leave the student independent thinking of time and space; encourage students to participate in classroom activities.

4) School environment: in addition to the atmosphere of the school, teaching equipment, teaching structure has important influence on teaching effect. The effective use of advanced teaching equipment can improve students' interest in learning mathematics, strengthen students to accurately grasp the degree of knowledge, ability to improve the effectiveness of classroom teaching and learning of mathematics. At the same time, teachers of noble character and high prestige and knowledgeable but also conducive to the students' Ideological and moral cultivation and knowledge learning. The teacher's idea, moral character and behavior of the students in the intangible life and values influence.

\section{Empirical Analysis}

\subsection{Questionnaire Survey}

The survey consists of two questionnaires, respectively, for the factors influence the effectiveness of classroom teaching of mathematics student's questionnaires and high school mathematics classroom teaching effectiveness factors questionnaire for teachers. The production of this questionnaire is under the guidance of the teacher, in reference to a large number of relevant information on the basis of the completion of the. Student's questionnaire issued 180 copies, 174 valid recoveries; the effective recovery rate was 96.7\%. The questionnaires were distributed to 18 parts, the effective recovery of 17 
copies; the effective recovery rate was $94.5 \%$. Release and recovery of the questionnaire is the researcher implemented, in order to improve the validity of the research on the use of. After the questionnaires were collected, I sort out the valid questionnaires, and the related data were presented in the form of tables, and the data were compared and analyzed.

Table 1. Composition of Effective Questionnaire

\begin{tabular}{|c|c|c|c|}
\hline Grade & Male & female & total \\
\hline first grade & 23 & 34 & 57 \\
\hline second grade & 25 & 34 & 59 \\
\hline Grade three & 30 & 28 & 58 \\
\hline total & 78 & 86 & 174 \\
\hline
\end{tabular}

First questionnaire is university mathematics teaching effectiveness influence factors, which participate in the survey are university students, these students participating in the survey is to generate a random sampling method was used to obtain the sample, the recovery of questionnaire and remove 6 valid questionnaires and 174 questionnaires effectively, students "efficiency was $96.7 \%$. The second questionnaire is a teacher questionnaire, which is the effective influencing factor of mathematics classroom teaching. The participants of this questionnaire are teachers, and they are also 18 math teachers from three grades of the school. In the recovery of the questionnaire, the effective rate of the teacher's questionnaire was $94.5 \%$.

\subsection{Teaching Situation}

From table 2 to table 4, the real pre class prep students accounted for very little, which only a small part of the preview of the students were correct and effective preview, can really achieve the preview effect, at the same time, teachers prepare lessons also mostly pauses in the preparation of teaching materials and teaching design. Preparing for the study of mathematics is very important, which requires teachers to improve the degree of attention to prepare before class, and guide the students to correct the preview before class. In addition, the teaching material is only a tool of teaching; the students are the real masters of the classroom. In order to achieve the effective classroom teaching, we must in-depth understanding of knowledge students, master students not only the existing cognitive structure, master students have the knowledge level, master student's mathematics learning psychology as well as the zone of proximal development, understand the teaching environment, make full use of teaching facilities.

Table 2. Students Prepare Situation

\begin{tabular}{|c|c|c|c|c|}
\hline Index & $\begin{array}{c}\text { Not } \\
\text { Preview }\end{array}$ & $\begin{array}{c}\text { Rarely } \\
\text { Preview }\end{array}$ & $\begin{array}{c}\text { Preview } \\
\text { assigned work }\end{array}$ & $\begin{array}{c}\text { Often } \\
\text { Preview }\end{array}$ \\
\hline number & 55 & 56 & 11 & 52 \\
\hline proportion & $32 \%$ & $33 \%$ & $6 \%$ & $29 \%$ \\
\hline
\end{tabular}

Table 3. Teachers Preparing Lessons

\begin{tabular}{|c|c|c|c|c|}
\hline Index & $\begin{array}{c}\text { teaching } \\
\text { material }\end{array}$ & $\begin{array}{c}\text { instructional } \\
\text { design }\end{array}$ & $\begin{array}{c}\text { Student } \\
\text { situation }\end{array}$ & $\begin{array}{c}\text { Teaching } \\
\text { environment }\end{array}$ \\
\hline number & 53 & 50 & 44 & 27 \\
\hline proportion & $30 \%$ & $32 \%$ & $24 \%$ & $14 \%$ \\
\hline
\end{tabular}


Table 4. Students Preview Mode

\begin{tabular}{|c|c|c|c|c|}
\hline Index & $\begin{array}{c}\text { Simply } \\
\text { see }\end{array}$ & $\begin{array}{c}\text { Determining } \\
\text { Importance }\end{array}$ & $\begin{array}{c}\text { Draw a } \\
\text { question }\end{array}$ & $\begin{array}{c}\text { Consult } \\
\text { data }\end{array}$ \\
\hline number & 65 & 46 & 52 & 11 \\
\hline proportion & $37.5 \%$ & $27 \%$ & $29 \%$ & $6.5 \%$ \\
\hline
\end{tabular}

According to table 6, we can see the teachers tend to exploration on cooperative learning approach to teaching, inquiry teaching, and they are more like. Students do not like the way of teaching will reduce their interest in learning mathematics, reduce the enthusiasm of learning mathematics, and affect the effectiveness of mathematics classroom teaching. Therefore, in the future, teachers should change the teaching idea, improve the teaching methods, and further improve the efficiency of classroom teaching.

Table 5. Learning Model That University Students Like

\begin{tabular}{|c|c|c|c|c|}
\hline Index & $\begin{array}{c}\text { Inquiry } \\
\text { Teaching }\end{array}$ & $\begin{array}{c}\text { Autonomous } \\
\text { Learning }\end{array}$ & $\begin{array}{c}\text { Teacher } \\
\text { explain }\end{array}$ & $\begin{array}{c}\text { Cooperative } \\
\text { learning }\end{array}$ \\
\hline number & 35 & 50 & 32 & 57 \\
\hline proportion & $20 \%$ & $29 \%$ & $18.5 \%$ & $32.5 \%$ \\
\hline
\end{tabular}

Table 6. Learning Model That University Teacher Like

\begin{tabular}{|c|c|c|c|c|}
\hline Index & $\begin{array}{c}\text { Teaching } \\
\text { style }\end{array}$ & $\begin{array}{c}\text { Question } \\
\text { type }\end{array}$ & $\begin{array}{c}\text { inquiry } \\
\text { teaching }\end{array}$ & other \\
\hline number & 56 & 49 & 38 & 30 \\
\hline proportion & $32 \%$ & $28 \%$ & $22 \%$ & $17 \%$ \\
\hline
\end{tabular}

\subsection{Student Participation}

From table 7 to table 8 , we can get that the main task of the students in class is to listen carefully, in the case of teachers to participate in classroom teaching activities; more teachers also just ask students to listen, to think. The whole classroom activities, teachers occupy the main position, cannot be left to the students enough time and space, reflecting the subjectivity of the students. Students are the real masters of the classroom teaching, in the process of classroom teaching to mobilize the enthusiasm of students, initiative, play the main role of the students, to play the leading role of teachers, to further improve the efficiency of classroom teaching.

Table 7. Student Participation in Mathematics Classroom

\begin{tabular}{|c|c|c|c|c|}
\hline Index & $\begin{array}{c}\text { Not } \\
\text { participate }\end{array}$ & $\begin{array}{c}\text { participate if } \\
\text { teacher } \\
\text { require }\end{array}$ & $\begin{array}{c}\text { participate } \\
\text { which he } \\
\text { think is } \\
\text { important }\end{array}$ & $\begin{array}{c}\text { actively } \\
\text { participate in }\end{array}$ \\
\hline number & 49 & 54 & 38 & 33 \\
\hline proportion & $28 \%$ & $31 \%$ & $22 \%$ & $19 \%$ \\
\hline
\end{tabular}


Table 8. Requirements of Teachers for Students

\begin{tabular}{|c|c|c|c|c|}
\hline Index & $\begin{array}{c}\text { listen } \\
\text { carefully }\end{array}$ & $\begin{array}{c}\text { Think } \\
\text { seriously }\end{array}$ & $\begin{array}{c}\text { Actively } \\
\text { participate }\end{array}$ & other \\
\hline number & 63 & 40 & 44 & 27 \\
\hline proportion & $36 \%$ & $23 \%$ & $25.5 \%$ & $15.5 \%$ \\
\hline
\end{tabular}

From table 9 to table 11, it shows that current students to learn mathematics, many of them were to do that, a few students to summarize, sum up, most of the students do not like to study mathematics, and mathematics learning efficiency is low. In fact, in the usual study, students have access to the mathematical has high degree of abstraction, the strict logic, students feel mathematics interesting, practical and mathematical beauty, just through repeated exercises and mechanical practice to learn math.

Table 9. The Way Students Learn Mathematics after Class

\begin{tabular}{|c|c|c|c|c|}
\hline Index & $\begin{array}{c}\text { Do math } \\
\text { problems }\end{array}$ & $\begin{array}{c}\text { Look at math } \\
\text { books }\end{array}$ & $\begin{array}{c}\text { Review the } \\
\text { knowledge }\end{array}$ & $\begin{array}{c}\text { Induction and } \\
\text { summary }\end{array}$ \\
\hline number & 85 & 28 & 27 & 33 \\
\hline proportion & $49.2 \%$ & $16.6 \%$ & $15.5 \%$ & $18.7 \%$ \\
\hline
\end{tabular}

Table 10. Students Learn Mathematics Efficiency

\begin{tabular}{|c|c|c|c|c|}
\hline Index & low & commonly & High & Very high \\
\hline number & 67 & 64 & 32 & 10 \\
\hline proportion & $38.6 \%$ & $37 \%$ & $18.4 \%$ & $6 \%$ \\
\hline
\end{tabular}

Table 11. Students' Interest in Mathematics Learning

\begin{tabular}{|c|c|c|c|c|}
\hline Index & low & Commonly & High & Very high \\
\hline number & 44 & 68 & 45 & 17 \\
\hline proportion & $25.1 \%$ & $39 \%$ & $26 \%$ & $9.9 \%$ \\
\hline
\end{tabular}

Through the analysis of the questionnaire we found that students and teachers agreed that preparation before class of mathematics learning is very important, but students do not master the correct preview method, do not know how to prepare a lesson, teachers don't have enough attention, has not been able to effectively guide. Careful teaching design is conducive to the mobilization of students' learning enthusiasm; stimulate the students' learning motivation, but teachers still use the traditional teaching methods. Students hope to be more involved in the classroom activities, the real master of the classroom, but the teacher did not leave enough time and space for students. Under the requirements of the new curriculum, the problem of teaching is very popular, but " $\mathrm{Q}$ " is not the core of the problem, "ask" is not a bootstrap value of problem, only pay attention to "ask" the surface, do not pay attention to "ask" to, heavy question light feedback phenomenon everywhere. Teachers know the correct way to learn to really learn the importance of math class, but few teachers in this to give students the correct and effective guide, perhaps is the college entrance examination baton let teacher mistakenly think that doing exercises is the only way to learn mathematics. In fact, such a mathematical learning method, the student's learning pressure, learning mood, learning efficiency is low, is not conducive to the comprehensive and sustainable development of students. This requires teachers to pay attention to the guidance of students' mathematics learning methods, and further research in this area, through the improvement of students' 
learning methods to improve students' learning efficiency, reduce the pressure of primary school students' learning.

\section{Conclusions}

Mathematics classroom teaching effectiveness testing should be comprehensive, dynamic and comprehensive, in pay attention to students has reached the level of knowledge at the same time to changes in the existing student and there exists the potential and development direction of attention. Testing is not only now the students understand the learning level, learning state, to determine the difficulties encountered errors students learning problems existing in the process, learning, learning, putting forward constructive suggestions for the further development of the students. Such evaluation can make teachers understand the effect of their teaching, master the learning process of the students, and provide the basis for improving teaching effect. The purpose of education is not simply to let students grasp the textbook knowledge, more important is to let the students through the in-depth understanding of the teaching content, learn to find problems, analyze problems, and solve problems. Therefore, in the process of teaching, not only to let students learn basic mathematical knowledge, but also to try to wake up the students' thirst for knowledge, to mobilize the enthusiasm of students to participate in classroom activities. Only students take the initiative to learn, really become the master of learning, other teaching work can be carried out smoothly. Pre class preparation, new class introduction, new knowledge learning, classroom questions, classroom practice and other aspects of classroom teaching should be carefully designed to combine teaching objectives. Students are the masters of the classroom teaching, classroom teaching is the direct object, so the above each link to original cognitive structure of students as a starting point, in the student's zone of proximal development guide students to think, to learn. Of course, the teaching design should meet the students' life, which is more conducive to stimulate students' enthusiasm for learning and improve their learning efficiency.

Effective teaching results are the premise of the development of people, is conducive to the further development and progress of students, is conducive to the individual development of students, is for the overall progress of the classroom teaching of all students. The result of teaching is the progress of all students, rather than the progress of individual students. The object of education is all the students accept education, to weigh the level of the final outcome of education or teaching efficiency, not to individual students to obtain the results as the object, and to to the overall development of all students as a measure of the object. Classroom teaching allows students to acquire basic knowledge and basic skills, but also to enable students to master the corresponding learning methods. In modern society, the knowledge update quickly, if the students learned the only knowledge, will not be able to adapt to the times demand, will be eliminated by the society; only to learn the methods of learning, can at any time and place to learn required knowledge, the pace to keep up with the times, for the society.

\section{Acknowledgments}

This work was supported by the research fund of key disciplinary of applied mathematics, Xihua University (Grant No.12ZB135, Grant No.Szjj2013-021).

\section{References}

[1] R. Khansa, "Teachers' Perceptions toward School Counselors in Selected Private Schools in Lebanon", Procedia-Social and Behavioral Sciences, vol. 185, (2015), pp. 381-387.

[2] M. Alavi, "The Challenges of High School Counselors in Work PlaceOriginal", Procedia-Social and Behavioral Sciences, vol. 46, (2012), pp. 4786-4792.

[3] R. A. Sabella, "School counselors perceived importance of counseling technology competencies", Computers in Human Behavior, vol. 26, (2010), pp. 609-617. 
[4] Z. Huang and M. Benyoucef, "From e-commerce to social commerce: A close look at design features", Electronic Commerce Research and Applications, vol. 12, no. 4, (2013), pp. 246-259.

[5] K. Anand, "Context-general and Context-specific Determinants of Online Satisfaction and Loyalty for Commerce and Content Sites", Journal of Interactive Marketing, vol. 24, no. 3, (2010), pp. 222-238.

[6] S. E. Carrell and M. Hoekstra, "Are school counselors an effective education input?", Economics Letters, vol. 125, (2014), pp. 66-69.

[7] L. Michel and R. Mohammad, "The effects of social media based brand communities on brand community markers, value creation practices, brand trust and brand loyalty", Computers in Human Behavior, vol. 28, no. 5, (2012), pp. 1755-1767.

[8] N. R. Mastroleo and R. Turrisi, "Examination of posttraining supervision of peer counselors in a motivational enhancement intervention to reduce drinking in a sample of heavy-drinking college students", Journal of Substance Abuse Treatment, vol. 39, (2010), pp. 289-297.

\section{Author}

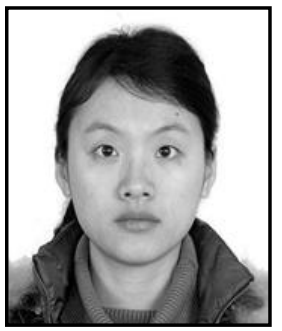

Cheng Na, 1982.10, Chengdu Sichuan 610031, China

Current position, grades: School of Science, Xihua University, Chengdu Sichuan 610031, P. R. China

Scientific interest: operators on Banach lattice

Publications: more than 10 papers published

Experience: She has teaching experience of 5 years. 
International Journal of Future Generation Communication and Networking Online Vol. 9, No. 4, (2016) 